\title{
Effect of enzyme addition, germination, and fermentation on the nutritive value of barley for growing Japanese quails
}

\author{
R. Kianfar ${ }^{1,4}$, H. Moravej', M. Shivazad ${ }^{2}$ and M. Taghinejad-Roudbaneh ${ }^{3}$ \\ 'University of Tabriz, Department of Animal Science, Faculty of Agriculture \\ 51666-14766 Tabriz, Iran \\ ${ }^{2}$ University of Tehran, Department of Animal Science, Faculty of Agricultural Science and Engineering, \\ College of Agriculture and Natural Resources \\ 31587-77871 Karaj, Iran \\ ${ }^{3}$ Islamic Azad University, Department of Animal Science,Tabriz branch, \\ 51579-44533 Tabriz, Iran
}

KEY WORDS: barley, enzyme, fermentation, germination, performance, Japanese quail
Received: 6 November 2012

Revised: 27 February 2013

Accepted: 13 June 2013

\begin{abstract}
Two experiments were conducted to study the effect of fermentation and germination on the nutritive value of barley for Japanese quail. In the first experiment, 72 male 13-week-old Japanese quails were used to determine the apparent metabolizable energy corrected for nitrogen $\left(\mathrm{AME}_{N}\right)$ of barley samples. In the second experiment, 720 7-day-old Japanese quails were randomly assigned to a $3 \times 3$ factorial design experiment. The factors include 3 processing methods (untreated, fermentation, germination) and $3(0$,

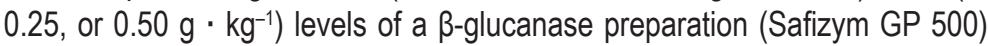
containing mainly $\beta$-glucanase activities. Each treatment group consisted of 4 replicates of 20 birds. Germination and fermentation decreased $(p<0.05)$ the non-starch polysaccharide (NSP) content and increased $(P<0.01)$ the $\mathrm{AME}_{\mathrm{N}}$ content of barley. Germination or fermentation of barley and addition of the enzyme preparation to the diet improved body weight gain, feed conversion ratio $(F C R)$, carcass, breast, and thigh weights of quails $(p<0.05)$. Fermentation of barley showed the highest impact on the reduction of NSP in barley and on performance in quails. It is concluded that fermentation and germination can be used to improve the growth rate and FCR of growing quail fed diets based on barley without supplementing enzymes, but fermentation has a better effect on performance and reduction of NSP.
\end{abstract}

${ }^{4}$ Corresponding author: e-mail: Ruhollahkianfar@gmail.com starch polysaccharides (NSP) that birds do not have the enzymatic capability to digest (Bedford, 1991). Newman et al. (1985) reported that fungal fermentation of barley may improve the performance of broiler chickens more than $\beta$-glucanase treatment. An earlier experiment showed that mixed-linked $\beta$-glucans were degraded during controlled short-time fermentation of barley (Skrede et al., 2002). Soaking and germination of whole barley prior to feeding improved the performance of broiler chickens to 
the same extent as addition of $\beta$-glucanase to the diet (Svihus et al., 1997a). During germination the biological value of the protein also increases because storage amino acids such as glutamine are converted to lysine and other essential amino acids (Singh and Sosulski, 1986).The effects of lactic acid fermentation and germination of barley on Japanese quail performance have not been reported. Hence, the purpose of the present study was to evaluate the effect of germination, fermentation and enzyme addition on the nutritive value of whole barley for growing Japanese quail and its effect on their growth performance and carcass yield.

\section{Material and methods}

\section{Processing procedure}

Fermentation. The barley was ground on a hammer mill with a $3.5 \mathrm{~mm}$ screen. The resulting flour was mixed with water $\left(30^{\circ} \mathrm{C}\right)$ at a ratio of $60 \%$ water to $40 \%$ barley flour and subsequently fermented in air-tight vessels with a Lactobacillus crispatus strain of broiler gut origin (Taheri et al., 2009). The fermentation mixture was inoculated with $1 \times 10^{6}$ colony forming units (CFU) per gram of barley flour and then kept at $30^{\circ} \mathrm{C}$. After $36 \mathrm{~h}$, the vessel contents were combined, spread on a heated floor and airdried for 7 days (Skrede et al., 2003). The fermented, dry barley flour was ground through a $5 \mathrm{~mm}$ screen before production of the experimental diets.

Germination. Barley was germinated as described by Carlson and Poulsen (2003) with minor modifications. Briefly, whole barley grain was soaked in pool at a ratio of $60 \%$ water to $40 \%$ barley at room temperature for $48 \mathrm{~h}$, then it was spread on a heated floor and air-dried for 7 days. The untreated and germinated dry barley grain was ground through a $5 \mathrm{~mm}$ screen before production of the experimental diets.

\section{Experiment 1}

A reference diet was formulated according to NRC recommendations (1994) to meet the nutrient requirements of growing Japanese quail (Table 1). For the experimental diets, $400 \mathrm{~g}$ of reference diet were exchanged with $400 \mathrm{~g} \cdot \mathrm{kg}^{-1}$ of finely ground untreated or processed barley and then mixed. Chromic oxide at $5.0 \mathrm{~g} \cdot \mathrm{kg}^{-1}$ of diet was mixed with the diets and used to calculate the dietary $\mathrm{AME}_{\mathrm{N}}$ value by the difference method. Gross energy efficiency was calculated by expressing AME $_{\mathrm{N}}$ value as a proportion of the gross energy.

Male quails (13 weeks old) were used in the study. Each dietary treatment was replicated 6 times with four quails per replication. Four quails were placed in each cage $(25 \times 21 \times 25 \mathrm{~cm})$ and each cage was equipped with an individual feeder, a drinker and a plastic-covered tray for collection of excreta. After feeding the quails the experimental diet for a 7-day adaptation period, they were then fasted for $24 \mathrm{~h}$, after which they were fed their respective reference or experimental diet in mash form ad libitum for 4 days. During that time excreta was collected twice daily at $12 \mathrm{~h}$ intervals.

\section{Experiment 2}

The experiment was conducted to study different methods of processing barley with or without supplemental NSP-degrading enzymes on quail performance. The birds were randomly assigned to a $3 \times 3$ factorial design. The factors were three processing methods (untreated, fermentation, germination) and three enzyme levels $\left(0,0.25\right.$ or $\left.0.5 \mathrm{~g} \cdot \mathrm{kg}^{-1}\right)$. A total of 720 as hatched 7-day-old Japanese quails were allocated to the nine treatments. Each treatment group consisted of 4 replicates of 20 birds of the same body weight $(528 \mathrm{~g})$. The birds were obtained from the hatchery of the animal research station of Tehran University. The quails were kept in wire cages $(60 \times 100 \times 50$ $\mathrm{cm})$ in a temperature-controlled room. The target room temperature was initially set to $38^{\circ} \mathrm{C}$ and then gradually decreased during the first $20 \mathrm{~d}$ of life to $20^{\circ} \mathrm{C}$. Diets and fresh water were offered ad libitum. The lighting schedule was 23L : 1D throughout the experiment. Ingredients and chemical composition of the experimental diet are shown in Table 1. The basal diet was formulated to meet or exceed the nutrient requirements of growing Japanese quail (NRC, 1994). The used enzyme (Safizym GP 500, SafAgri/Lesaffre Feed Additives, Milwaukee, USA) contained mainly $\beta$-glucanase. According to the manufacturer, the $\beta$-glucanase activity was 5600 units $\cdot \mathrm{g}^{-1}$. During the experimental period, the growth performance of quails was evaluated by recording body weight (BW) and feed intake (FI). Body weight gain (BWG) and feed conversion ratio (FCR, $\mathrm{kg}$ feed $\cdot \mathrm{kg}^{-1}$ BWG) were calculated. Quails were weighed by pen at the beginning of the experiment and on a weekly basis thereafter. Water consumption was recorded daily by checking the volume of water left in the drinkers at the end of each day and subtracting this from all water allocated to each drinker in the preceding $24 \mathrm{~h}$ period, then water to feed intake ratio (WFR) was calculated. At the end of the experiment, 6 quails ( 3 males and 3 females) with a BW close to the group average 
Table 1. Composition of experimental quail diets as calculated ${ }^{1}$ and analysed of the ingredients, $\mathrm{g} \cdot \mathrm{kg}^{-1}$

\begin{tabular}{|c|c|c|c|c|c|c|c|}
\hline \multirow{2}{*}{ Ingredient } & \multicolumn{4}{|c|}{ Diets for measuring $\mathrm{AME}_{N}$} & \multicolumn{3}{|c|}{ Diets for performance trail } \\
\hline & Reference & $\mathrm{UT}^{1}$ & $\mathrm{GR}^{2}$ & $\mathrm{FR}^{3}$ & UT & GR & FR \\
\hline Barley & 0 & 400 & 400 & 400 & 400 & 400 & 400 \\
\hline Maize & 579.9 & 346.8 & 346.8 & 346.8 & 204 & 204 & 204 \\
\hline Soya bean meal (430) & 303.3 & 181.4 & 181.4 & 181.4 & 219.6 & 219.6 & 219.6 \\
\hline Maize gluten meal (640) & 75.90 & 45.39 & 45.39 & 45.39 & 118.1 & 118.1 & 118.1 \\
\hline Soya oil & 0 & 0 & 0 & 0 & 20 & 20 & 20 \\
\hline Oyster shell & 13.4 & 8.04 & 8.04 & 8.04 & 14 & 14 & 14 \\
\hline Dicalcium phosphate & 8.5 & 5.10 & 5.10 & 5.10 & 8.5 & 8.5 & 8.5 \\
\hline $\mathrm{NaCl}$ & 2.9 & 1.74 & 1.74 & 1.74 & 3 & 3 & 3 \\
\hline Mineral premix ${ }^{4}$ & 2.5 & 1.5 & 1.5 & 1.5 & 2.5 & 2.5 & 2.5 \\
\hline Vitamin premix ${ }^{5}$ & 2.5 & 1.5 & 1.5 & 1.5 & 2.5 & 2.5 & 2.5 \\
\hline L-threonine (980) & 1.4 & 0.84 & 0.84 & 0.84 & 2 & 2 & 2 \\
\hline DL-methionine (980) & 1.0 & 0.66 & 0.66 & 0.66 & 0.9 & 0.9 & 0.9 \\
\hline L-lysine $\mathrm{HCl} 744$ & 3.5 & 2.1 & 2.1 & 2.1 & 5 & 5 & 5 \\
\hline $\mathrm{Cr}_{2} \mathrm{O}_{3}$ & 5 & 5 & 5 & 5 & 0 & 0 & 0 \\
\hline \multicolumn{8}{|c|}{ Analysed composition, $\mathrm{g} \cdot \mathrm{kg}^{-1}$} \\
\hline dry matter & 90.1 & 91.4 & 90.9 & 90.5 & 92.2 & 91.7 & 91.4 \\
\hline crude protein & 240 & 187.4 & 188.4 & 188.4 & 240 & 241 & 241 \\
\hline lysine & 13.2 & 9.4 & 9.53 & 9.81 & 13.1 & 13.2 & 13.4 \\
\hline methionine + cysteine & 7.9 & 6.8 & 6.91 & 6.9 & 7.7 & 7.7 & 7.8 \\
\hline threonine & 10.2 & 7.3 & 8.0 & 8.80 & 10.3 & 11.1 & 11.9 \\
\hline ether extract & 30.7 & 29.6 & 29.2 & 28.8 & 46.5 & 46.1 & 45.7 \\
\hline $\mathrm{AME}_{\mathrm{N}}, \mathrm{MJ} \cdot \mathrm{kg}^{-1}$ & 12.1 & 11.6 & 11.8 & 12.4 & 11.8 & 12.1 & 12.6 \\
\hline calcium & 8 & 4.9 & 4.9 & 4.9 & 8 & 8 & 8 \\
\hline total phosphorus & 5.61 & 4.73 & 4.73 & 4.73 & 5.63 & 5.63 & 5.63 \\
\hline total ash & 50.2 & 41.52 & 41.56 & 41.52 & 53.86 & 53.90 & 53.86 \\
\hline
\end{tabular}

${ }^{1}$ untreated, ${ }^{2}$ germinated, ${ }^{3}$ fermented, ${ }^{4}$ supplemented kg-1 diet; mg: Fe 50, Mn 102, Zn 70, Cu 10, I 0.5, Se 0.2, ${ }^{5}$ supplemented kg ${ }^{-1}$ diet; vit.; IU: $\mathrm{A} 12,000, \mathrm{D}_{3} 360$; $\mathrm{mg}$ : a-tocopheryl acetate 50 , vit. $\mathrm{K}_{3} 33$, thiamin 2.5 , riboflavin 12 , pyridoxine 4.5 , pantothenic acid 16.65 , biotin 0.26 , folacin 2 , niacin 50 , vit. $B_{12} 0.025$

were selected from each of the replicate groups in each treatment, leg banded, then slaughtered by severing the jugular vein, to determine slaughter yield. Carcass yield was calculated as the ratio of empty BW relative to live BW. Thigh quarters were obtained by separating the thigh from the back at the joint between the femur and ilium, and by separating the tibia and shank at the hock joint. The whole breast portion was obtained by cutting through the ribs, thereby separating the breast portion from the back. Part yields refer to the part weight/eviscerated weight ratio.

\section{Measurements and chemical analyses}

The dry matter (DM), ash, crude protein, fat, calcium and phosphorus of diets, barley samples and excreta were determined by AOAC (1980) methods. Amino acid analysis was performed using an amino acid analyzer (LKB, UK). Soluble and insoluble NSP and dietary fibre were determined by a modified method based on AOAC (2005; method 991.43) and AACC (2009; method 32-07). Total and insoluble $\beta$-glucans were assayed enzymatically using commercial kits (Megazyme. Ireland). The $\mathrm{pH}$ of samples was measured with a portable digital $\mathrm{pH}$ meter. Colony forming units of lactic acid bacteria were determined by spreading barley sample on plate agar and incubation at $25^{\circ} \mathrm{C}$ for 3 days according to NMKL (1997).

The dried feed and excreta samples were ground and assayed for gross energy using a Gallenkamp Ballistic Bomb Calorimeter (Gallenkamp, Loughborough, UK). The concentration of chromic oxide in the excreta samples was measured using the procedure described by Williams et al. (1962) and energy corrected for nitrogen was calculated (Choct et al., 1995) as follows:

$\mathrm{AME} / \mathrm{g}$ feed $=\mathrm{GEfd}-\left\{\left(\mathrm{Cr}_{2} \mathrm{O}_{3} \mathrm{fd} / \mathrm{Cr}_{2} \mathrm{O}_{3} \mathrm{fc}\right) \times \mathrm{GEfc}\right\}$ $A M E_{N} / g$ feed $=A M E / g$ feed- $8.73\left\{\mathrm{Nfd}-\left(\mathrm{Cr}_{2} \mathrm{O}_{3} \mathrm{fd} /\right.\right.$

$$
\left.\left.\mathrm{Cr}_{2} \mathrm{O}_{3} \mathrm{fc}\right) \times \mathrm{Nfc}\right\}
$$

where: $\mathrm{Cr}_{2} \mathrm{O}_{3} \mathrm{fd}-$ chromic oxide/g feed; $\mathrm{Cr}_{2} \mathrm{O}_{3} \mathrm{fc}$ - chromic oxide/g excreta; GEfd - gross energy/g feed; GEfc - gross energy/g excreta; Nfd nitrogen/g feed; $\mathrm{Nfc}$ - nitrogen/g excreta. $\mathrm{AME}_{\mathrm{N}}$ barley $-\mathrm{AME}_{\mathrm{N}}$ reference diet $-\left[\left(\mathrm{AME}_{\mathrm{N}}\right.\right.$ reference diet $-\mathrm{AME}_{\mathrm{N}}$ test diet)/substitution level]. 


\section{Statistical analyses}

The data from $\mathrm{AME}_{\mathrm{N}}$ values were analyzed as a completely randomized design and subjected to ANOVA using the GLM procedure of SAS software including the fixed effects of processing (SAS, 2001). The data from the feeding experiments were analysed by two-way ANOVA using a general linear model, effects of processing $(n=3)$, levels of enzyme $(\mathrm{n}=3)$, and their interaction. Significant differences among treatment means were determined at $p<0.05$ by Tukey's test (Steel and Torrie, 1980) when significant $F$ values were obtained. Root mean square error (RMSE) for each parameter was calculated as the square root of the residual mean squares.

\section{Results}

\section{Effects of processing on barley chemical composition}

The chemical compositions of the untreated and processed barley are presented in Table 2. Fermentation and germination of barley increased the number of CFU of lactic acid bacteria with a simultaneous reduction in the $\mathrm{pH}$ values of processed samples.
Total dietary fibre, and total and soluble $\beta$-glucans and NSP decreased in the barley during fermentation and germination resulting in increased $(p<0.05)$ gross energy efficiency (GEE).

\section{Effects of processing and enzyme addition on growth performance in quails}

The results from the growth experiment are presented in Table 3. Fermentation and germination in comparison with the untreated group increased BWG $(P<0.01)$. Processing of barley had no effect $(p>0.05)$ on the FI of quails. Fermentation and germination of barley decreased $(P<0.01)$ the FCR of quail compared with the untreated barley diet. Processing of barley decreased WFR $(p<0.05)$.

BWG was affected by enzyme supplementation of the diet $(P<0.01)$, increasing from $210 \mathrm{~g}$ to $226 \mathrm{~g}$. The BWG in quail fed diets containing 0.25 or 0.50 $\mathrm{g} \cdot \mathrm{kg}^{-1}$ enzyme did not differ $(p>0.05)$. Enzyme addition reduced the FCR $(p<0.05)$, but there were no differences among the levels of added enzyme. The water-to-feed intake ratio was also not affected by the level of enzymes in the diet, but the addition of enzymes decreased it. There was no interaction of main effects on BW, BWG, FI or WFR, but

Table 2. Influence of processing on chemical composition $\left(\mathrm{g} \cdot \mathrm{kg}^{-1} \mathrm{DM}\right), \mathrm{AME}_{\mathrm{N}}$ value of barley, $\mathrm{pH}$ and lactic acid bacteria counts ${ }^{1}$ of barley

\begin{tabular}{|c|c|c|c|c|c|}
\hline Indices & Untreated & Germinated & Fermented & $\mathrm{SEM}^{2}$ & $P$ \\
\hline Dry matter, $\mathrm{g} \cdot \mathrm{kg}^{-1}$ & 93.3 & 92 & 91.1 & & \\
\hline Crude protein & 108.7 & 111.2 & 111.1 & & \\
\hline Lysine, $\mathrm{g} \cdot \mathrm{kg}^{-1}$ & 4 & 4.3 & 4.9 & & \\
\hline Methionine, $\mathrm{g} \cdot \mathrm{kg}^{-1}$ & 1.9 & 1.9 & 2.0 & & \\
\hline Cysteine, $\mathrm{g} \cdot \mathrm{kg}^{-1}$ & 2.3 & 2.4 & 2.5 & & \\
\hline Threonine, $\mathrm{g} \cdot \mathrm{kg}^{-1}$ & 3.5 & 3.7 & 3.9 & & \\
\hline Ether extract, $\mathrm{g} \cdot \mathrm{kg}^{-1}$ & 28 & 27 & 26 & & \\
\hline Total ash, $\mathrm{g} \cdot \mathrm{kg}^{-1}$ & 28.5 & 28.6 & 28.5 & & \\
\hline Calcium, $\mathrm{g} \cdot \mathrm{kg}^{-1}$ & 0.4 & 0.4 & 0.4 & & \\
\hline Phosphorus, $\mathrm{g} \cdot \mathrm{kg}^{-1}$ & 3.4 & 3.4 & 3.4 & & \\
\hline Lactic acid bacteria CFU $\cdot \mathrm{g}^{-1}$ & $2 \times 10^{3}$ & $2 \times 10^{5}$ & $2 \times 10^{10}$ & & \\
\hline Total dietary fibre, $\mathrm{g} \cdot \mathrm{kg}^{-1}$ & 241.25 & 217 & 189.75 & & \\
\hline $\mathrm{pH}$ & 6 & 4.2 & 3.5 & & \\
\hline \multicolumn{6}{|l|}{$\mathrm{NSP}, \mathrm{g} \cdot \mathrm{kg}^{-1}$} \\
\hline total & 206.25 & 185 & 161.75 & & \\
\hline soluble & 47.25 & 32 & 27 & & \\
\hline insoluble & 159 & 153 & 134.75 & & \\
\hline insoluble/soluble ratio & 3.38 & 4.47 & 4.96 & & \\
\hline \multicolumn{6}{|l|}{$\beta$-glucans, $\mathrm{g} \cdot \mathrm{kg}^{-1}$} \\
\hline total & 37.6 & 26.05 & 22.77 & & \\
\hline soluble & 23.92 & 13.25 & 10.80 & & \\
\hline insoluble & 13.67 & 12.80 & 11.97 & & \\
\hline insoluble/soluble ratio & 0.57 & 0.96 & 1.11 & & \\
\hline$A M E_{N}, M J \cdot \mathrm{kg}^{-1}$ & $10.95^{c}$ & $11.47^{b}$ & $12.90^{\mathrm{a}}$ & 0.065 & $<0.01$ \\
\hline $\mathrm{GEE}^{3}$ & $0.666^{c}$ & $0.697^{b}$ & $0.764^{\mathrm{a}}$ & 0.0018 & $<0.01$ \\
\hline
\end{tabular}

a,b,c mean values within a column with no common letters are significantly different $(p \leq 0.05)$ as determined by least significant difference comparison; ${ }^{1}$ mean values of the 8 replicate analyses, ${ }^{2}$ standard error of means, ${ }^{3}$ gross energy efficiency $=\mathrm{AME}_{\mathrm{N}} / \mathrm{gross}$ energy 
Table 3. Effects of barley processing and enzyme supplementation on performance of Japanese quails between 7 and 42 day and water to feed intake ratio (WFR)

\begin{tabular}{|c|c|c|c|c|c|}
\hline Indices & $\mathrm{BW}, \mathrm{g}$ & BWG, $g$ & FCR, $g$ feed $\cdot g^{-1}$ BWG & Feed intake, $g$ & WFR \\
\hline \multicolumn{6}{|l|}{ Processing } \\
\hline $\mathrm{UT}^{1}$ & $236.3^{b}$ & $209.8^{b}$ & $3.60^{c}$ & 755.2 & $2.61^{b}$ \\
\hline $\mathrm{GR}^{2}$ & $245.4^{\mathrm{a}}$ & $219.0^{a}$ & $3.51^{\mathrm{b}}$ & 768.0 & $2.40^{\mathrm{b}}$ \\
\hline $\mathrm{FR}^{3}$ & $254.6^{a}$ & $228.1^{\mathrm{a}}$ & $3.33^{\mathrm{a}}$ & 762.1 & $2.39^{a}$ \\
\hline P-value & $<0.01$ & $<0.01$ & $<0.01$ & NS & 0.05 \\
\hline SEM $^{4}$ & 2.25 & 2.25 & 0.02 & 7.34 & 0.06 \\
\hline \multicolumn{6}{|c|}{ Enzyme, $\mathrm{g} \cdot \mathrm{kg}^{-1}$} \\
\hline 0 & $237.1^{b}$ & $210.6^{b}$ & $3.58^{c}$ & 753.3 & 2.51 \\
\hline 250 & $246.0^{\mathrm{a}}$ & $219.6^{a}$ & $3.48^{b}$ & 765.0 & 2.50 \\
\hline 500 & $253.2^{\mathrm{a}}$ & $226.7^{a}$ & $3.38^{\mathrm{a}}$ & 767.0 & 2.39 \\
\hline P-value & 0.02 & 0.05 & $<0.01$ & NS & NS \\
\hline SEM & 2.25 & 2.25 & 0.02 & 7.34 & 0.06 \\
\hline \multicolumn{6}{|l|}{$P \times E^{5}$} \\
\hline $\mathrm{UT} \times 0$ & 223.4 & 197.0 & $3.76^{d}$ & 741.3 & 2.67 \\
\hline UT × 0.25 & 237.6 & 211.1 & $3.61^{\mathrm{cd}}$ & 762.8 & 2.63 \\
\hline UT $\times 0.50$ & 247.9 & 221.5 & $3.43^{\mathrm{abc}}$ & 761.3 & 2.52 \\
\hline $\mathrm{GR} \times 0$ & 241.3 & 214.8 & $3.60^{\text {cd }}$ & 774.3 & 2.47 \\
\hline $\mathrm{GR} \times 0.25$ & 244.2 & 217.7 & $3.51^{\mathrm{bc}}$ & 764.8 & 2.47 \\
\hline$G R \times 0.50$ & 250.8 & 224.4 & $3.40^{a b}$ & 764.9 & 2.28 \\
\hline $\mathrm{FR} \times 0$ & 246.6 & 220.2 & $3.37^{\mathrm{ab}}$ & 744.2 & 2.40 \\
\hline$F R \times 0.25$ & 256.3 & 229.9 & $3.33^{\mathrm{ab}}$ & 767.2 & 2.40 \\
\hline $\mathrm{FR} \times 0.50$ & 260.8 & 234.3 & $3.30^{\mathrm{a}}$ & 774.8 & 2.39 \\
\hline P-value & NS & NS & 0.03 & NS & NS \\
\hline SEM & 3.9 & 3.9 & 0.035 & 12.7 & 0.11 \\
\hline
\end{tabular}

a,b,c mean values within a column in each section (processing or enzyme) with no common letters are significantly different $(p \leq 0.05)$ as determined by least significant difference comparison; ${ }^{1}$ untreated, ${ }^{2}$ germinated, ${ }^{3}$ fermented, ${ }^{4}$ standard error of means (two-way ANOVA), ${ }^{5}$ processing $\times$ enzyme interactions; BW - body weight, BWG - body weight gain, FCR - feed conversion ratio, WFR - feed intake ratio

Table 4. Effects of barley processing and enzyme supplementation on carcass quality of male and female Japanese quails

\begin{tabular}{|c|c|c|c|c|c|c|c|c|c|c|}
\hline \multirow{3}{*}{ Indices } & \multicolumn{4}{|c|}{ Carcass } & \multirow{2}{*}{\multicolumn{2}{|c|}{ Breast }} & \multirow{2}{*}{\multicolumn{2}{|c|}{$\begin{array}{c}\text { Thigh } \\
\text { weight, } g\end{array}$}} & \multirow{2}{*}{\multicolumn{2}{|c|}{ Abdominal fat }} \\
\hline & \multicolumn{2}{|c|}{ Weight, $g$} & \multicolumn{2}{|c|}{$\%$ of LBW } & & & & & & \\
\hline & $\mathrm{F}$ & $M$ & $\mathrm{~F}$ & $M$ & $\mathrm{~F}$ & $\mathrm{M}$ & $\mathrm{F}$ & $M$ & $\mathrm{~F}$ & $M$ \\
\hline \multicolumn{11}{|l|}{ Processing } \\
\hline $\mathrm{UT}^{1}$ & $151.2^{b}$ & $158.8^{b}$ & $62.2^{b}$ & 70.12 & $56.62^{c}$ & $71.4^{\mathrm{b}}$ & $37.6^{\mathrm{b}}$ & 41.9 & $0.65^{b}$ & $0.48^{b}$ \\
\hline $\mathrm{GR}^{2}$ & $159.8^{b}$ & $165.0^{\mathrm{a}}$ & $62.1^{\mathrm{b}}$ & 70.76 & $64.4^{\mathrm{b}}$ & $72.9^{a b}$ & $40.4^{\mathrm{ab}}$ & 43.3 & $1.09^{a b}$ & $0.63^{\mathrm{ab}}$ \\
\hline $\mathrm{FR}^{3}$ & $169.0^{\mathrm{a}}$ & $168.2^{\mathrm{a}}$ & $63.8^{\mathrm{a}}$ & 70.84 & $68.7^{\mathrm{a}}$ & $74.6^{\mathrm{a}}$ & $44.1^{\mathrm{a}}$ & 44.3 & $1.45^{a}$ & $0.83^{a}$ \\
\hline P-value & $<0.01$ & $<0.01$ & $<0.01$ & NS & $<0.01$ & 0.04 & $<0.01$ & NS & 0.04 & $<0.01$ \\
\hline SEM $^{4}$ & 1.84 & 1.04 & 0.21 & 0.56 & 1.12 & 0.87 & 1.04 & 0.69 & 0.21 & 0.06 \\
\hline \multicolumn{11}{|c|}{ Enzyme, $\mathrm{g} \cdot \mathrm{kg}^{-1}$} \\
\hline 0 & $154.6^{b}$ & $159.9^{b}$ & $63.1^{\mathrm{a}}$ & $71.1^{\mathrm{a}}$ & $61.6^{b}$ & $69.9^{b}$ & $38.9^{b}$ & $41.5^{b}$ & 0.88 & $0.50^{\mathrm{b}}$ \\
\hline 0.25 & $156.9^{b}$ & $161.6^{b}$ & $61.4^{b}$ & $69.4^{b}$ & $63.5^{\mathrm{b}}$ & $71.9^{b}$ & $39.5^{b}$ & $42.5^{b}$ & 1.04 & $0.65^{\mathrm{ab}}$ \\
\hline 0.50 & $165.5^{\mathrm{a}}$ & $170.6^{a}$ & $63.7^{\mathrm{a}}$ & $70.9^{\mathrm{ab}}$ & $67.5^{\mathrm{a}}$ & $77.2^{\mathrm{a}}$ & $43.6^{a}$ & $45.6^{\mathrm{a}}$ & 1.27 & $0.79^{\mathrm{a}}$ \\
\hline P-value & $<0.01$ & $<0.01$ & $<0.01$ & 0.04 & $<0.01$ & $<0.01$ & $<0.01$ & $<0.01$ & NS & 0.01 \\
\hline SEM & 1.84 & 1.04 & 0.21 & 0.56 & 1.12 & 0.87 & 1.04 & 0.69 & 0.21 & 0.06 \\
\hline \multicolumn{11}{|l|}{$P \times E^{5}$} \\
\hline UT $\times 0$ & 144.0 & $147.4^{\mathrm{e}}$ & $62.4^{\mathrm{bc}}$ & $69.7^{\mathrm{ab}}$ & 55.0 & 66.4 & 34.0 & 38.7 & 0.42 & 0.27 \\
\hline UT $\times 0.25$ & 151.7 & $161.0^{\mathrm{bc}}$ & $61.7^{\circ}$ & $70.4^{\mathrm{ab}}$ & 61.0 & 70.9 & 36.7 & 41.5 & 0.55 & 0.50 \\
\hline UT $\times 0.50$ & 157.9 & $168.1^{\mathrm{abc}}$ & $62.6^{\mathrm{bc}}$ & $70.2^{\mathrm{ab}}$ & 62.7 & 76.7 & 41.9 & 45.6 & 0.98 & 0.67 \\
\hline$G R \times 0$ & 153.1 & $164.7^{\mathrm{bc}}$ & $61.7^{c}$ & $70.5^{\mathrm{ab}}$ & 62.9 & 70.8 & 39.6 & 43.6 & 0.91 & 0.52 \\
\hline $\mathrm{GR} \times 0.25$ & 153.5 & $160.8^{c}$ & $61.0^{c}$ & $69.8^{\mathrm{ab}}$ & 62.7 & 72.2 & 38.6 & 42.1 & 1.11 & 0.64 \\
\hline $\mathrm{GR} \times 0.50$ & 163.9 & $169.6^{\mathrm{ab}}$ & $63.7^{\mathrm{ab}}$ & $71.8^{\mathrm{ab}}$ & 67.5 & 75.6 & 43.0 & 44.3 & 1.25 & 0.72 \\
\hline $\mathrm{FR} \times 0$ & 166.8 & $167.6^{\mathrm{abc}}$ & $65.2^{\mathrm{a}}$ & $74.0^{\mathrm{a}}$ & 67.0 & 72.3 & 43.1 & 42.2 & 1.32 & 0.73 \\
\hline $\mathrm{FR} \times 0.25$ & 165.5 & $162.9^{\mathrm{bc}}$ & $61.4^{c}$ & $67.8^{\mathrm{b}}$ & 66.7 & 72.4 & 43.4 & 44.0 & 1.45 & 0.81 \\
\hline $\mathrm{FR} \times 0.50$ & 174.6 & $174.1^{\mathrm{a}}$ & $64.8^{\mathrm{a}}$ & $70.5^{\mathrm{ab}}$ & 72.2 & 79.1 & 45.8 & 46.7 & 1.59 & 0.97 \\
\hline P-value & NS & $<0.01$ & $<0.01$ & 0.01 & NS & NS & NS & NS & NS & NS \\
\hline SEM & 3.20 & 3.31 & 0.38 & 0.98 & 1.95 & 1.52 & 1.80 & 1.19 & 0.37 & 0.10 \\
\hline Sex effect & 159 & 164.02 & 62.72 & 70.52 & 64.19 & 72.93 & 40.68 & 43.19 & 1.06 & 0.65 \\
\hline P-value & \multicolumn{2}{|r|}{$<0.01$} & \multicolumn{2}{|c|}{$<0.01$} & \multicolumn{2}{|c|}{$<0.01$} & \multicolumn{2}{|c|}{$<0.01$} & \multicolumn{2}{|r|}{$<0.01$} \\
\hline SEM & \multicolumn{2}{|r|}{1.38} & \multicolumn{2}{|c|}{0.27} & \multicolumn{2}{|c|}{0.76} & \multicolumn{2}{|r|}{0.62} & \multicolumn{2}{|r|}{0.09} \\
\hline
\end{tabular}

\footnotetext{
a,b,c see Table 3; 1,2,3,4,5 see Table 3
} 
the addition of enzymes decreased it. There the effect of enzymes on the FCR of groups fed fermented barley was not significant, while in groups fed untreated and germinated barley, it was significant (interaction treatment $\mathrm{x}$ enzyme significant at $p<0.05)$.

\section{Effects of processing and enzyme addition on carcass parameters}

The measured carcass parameters are presented in Table 4. Processing significantly increased the carcass weight $(\mathrm{CW})$ of male $(\mathrm{M})$ and female $(\mathrm{F})$ quails. The highest $\mathrm{CW}$ in both $\mathrm{M}$ and $\mathrm{F}$ quails was recorded in the group fed the diet containing fermented barley $(p<0.05)$. Moreover, adding enzymes improved the effect of fermentation on $\mathrm{CW}(p<0.05)$ and the best result was observed with $0.5 \mathrm{~g} \cdot \mathrm{kg}^{-1}$ enzymes $(p<0.05)$.

Briefly, processing and enzyme addition increased the breast weight in male and female quails and female thigh weight $(p<0.05)$. Processing of barley increased the abdominal fat weight in both sexes $(p<0.05)$, although only in male quails was abdominal fat weight increased $(p<0.05)$ following enzyme addition. Carcass yield increased by processing barley and adding enzymes, but the effect was more evident in female quails $(p<0.05)$.

\section{Discussion}

The reduced total dietary fibre, NSP, and $\beta$-glucan contents after germination of whole barley are in accordance with results obtained earlier (Svihus et al., 1996, 1997a), although the content of insoluble NSP decreased during high-moisture storage in those experiments. The improved performance of quail by feeding germinated barley could be attributed to decreased $\beta$-glucan and NSP contents. Reduced viscosity after germination has also been reported before (Svihus et al., 1997a). Svihus et al. (1997a) found that high-moisture storage reduced the soluble $\beta$-glucan content despite inhibition of enzyme activity by heat treatment. Svihus et al. (1997b) reported that germination and enzyme addition increase the nutritional value of whole barley diets to similar extents. The increased $\mathrm{AME}_{\mathrm{N}}$ after germination is in accordance with results obtained earlier (Svihus et al., 1997b). The $\mathrm{AME}_{\mathrm{N}}$ of untreated and germinated barley compared with fermented barley were significantly lower. It seems that germination in comparison with fermentation may be a less effective method for decreasing the anti-nutritive properties of barley soluble fibre for poultry. An increased ratio of insoluble to soluble $\beta$-glucans and NSP may be favourable for chicken performance, as the negative effects of $\beta$-glucans are mainly associated with the soluble fraction (Skrede et al., 2003). This was confirmed in the present study, since the ratio of insoluble to soluble $\beta$-glucans and NSP during fermentation and germination in comparison with untreated barley increased, and this ratio was higher for fermented barley. This indicates that reduced $\beta$-glucan solubility due to fermentation may have contributed to improved quail performance.

The present study showed beneficial effects of feeding fermented and germinated barley on BW, BWG and FCR in quails. The increased BWG and decreased FCR when fermented barley was fed are in agreement with Skrede et al. (2003). Lowered FCR in quail fed fermented barley points to a beneficial effect of fermentation on nutrient digestibility and energy utilization, as was shown previously in mink and salmon (Skrede et al., 2001, 2002). In the present study, the amount of abdominal fat increased significantly with feeding fermented barley. Higher fat deposition can increase the energy expenses associated with growth in the finishing period, and may have concealed the effects of fermentation on nutrient digestibility. With processing barley, the WFR significantly decreased. This indicates that water intake was reduced due to the $\beta$-glucan-lowering effect of fermentation and germination. As the final body weight increased due to barley processing or enzyme addition, the yield of eviscerated carcass, breast and thigh improved. The effects of fermenting barley on quail performance may be partly due to the $\beta$-glucanase activity of the selected Lactobacillus strain. Lactobacilli with $\beta$-glucan reducing abilities have previously been reported by Jonsson and Hemmingsson (1991).

Enzyme addition improves the BWG and FCR of quails. The beneficial effect of the use of exogenous enzymes in the present study was observed only in quails receiving diets containing untreated barley. This shows that processing the barley used in quail diets can improve nutrient digestibility without the need for addition of feed enzymes.

\section{Conclusions}

In conclusion, fermentation and germination can be used to improve the performance of growing quail fed diets based on barley without using enzymes, but fermentation has a better effect on performance and reduction of non-starch polysaccharide than untreated and germinated barley. 


\section{References}

AACC, 2009. Determination of Soluble, Insoluble and Total Dietary Fiber in Foods and Food Products. AACC International Approved Methods of Analysis. $11^{\text {th }}$ Edition. AACC International Press. St. Paul, MN

AOAC, 1980. Association of Official Analytical Chemists, Official Methods of Analysis. $13^{\text {th }}$ Edition. Washington, DC

AOAC, 2005. Association of Official Analytical Chemists, Official Methods of Analysis. $18^{\text {th }}$ Edition. Arlington, VA

Bedford M.,1991. Digestive Constraints in Monogastric Feedstuffs and Theoretical Opportunities for Supplementary Enzymes. Feed Enzyme Seminar, Broadway, Worcestershire, Finnfeeds Int. Ltd (UK)

Carlson D., Poulsen H.D., 2003. Phytate degardation in soaked and fermented liquid feed - effect of diet, time of incubation, heat treatment, phytase activity, $\mathrm{pH}$ and temperature. Anim. Feed Sci. Tech. 103,141-154

Choct M., Hughes R.J., Trimble R.P., Angkanaporn K., Annison G., 1995. Non-starch polysaccharide degrading enzymes increase the performance of broiler chickens fed wheat of low apparent metabolizable energy. J. Nutr. 125, 485-492

Jonsson E., Hemmingsson S., 1991. Establishment in the piglet gut of lactobacilli capable of degrading mixed-linked $\beta$-glucans. J. Appl. Microbiol. 70, 512-516

Newman R.K., Newman C.W., Eslick R.F., 1985. Effect of fungal fermentation and other treatments on nutritional value of waxy barley fed to chicks. Poultry Sci. 64, 1514-1518

NMKL, 1997. Aerobic Micro-organisms (Plate Count). Determination by the Plate Count Method at $30^{\circ} \mathrm{C}$ in Milk, Cream and Icecream. Method No. 27. $3^{\text {rd }}$ Edition. Nordic Committee on Food Analysis, Espoo (Finland)

NRC, 1994. Nutrient Requirements of Poultry. National Academy Press. Washington, DC

SAS, 2001. SAS/STAT User's Guide version 9.1. SAS Institute Inc. Cary. NC

Shim K.F., Vohra P., 1984. A review of the nutrition of Japanese quail. World Poultry Sci. J. 40, 261-264
Singh T., Sosulski F.W., 1986. Amino acid composition of malts: effect of germination and gibberellic acid on hulled and hulless barley and utility wheat. J. Agr. Food Chem. 34, 1012-1016

Skrede G., Herstad O., Sahlstrøm S., Holck A., Slinde E., Skrede A., 2003. Effects of lactic acid fermentation on wheat and barley carbohydrate composition and production performance in the chicken. Anim. Feed Sci. Tech. 105, 135-148

Skrede G., Sahlstrøm S., Skrede A., Holck A., Slinde E., 2001. Lactic acid fermentation of wheat and barley whole meal flour modifies carbohydrate composition and increases digestibility in mink (Mustelavison). Anim. Feed Sci. Tech. 90, 199-212

Skrede G., Storebakken T., Skrede A., Sahlstrøm S., Sørensen M., Shearer K.D., Slinde E., 2002. Lactic acid fermentation of wheat and barley whole meal flours improves digestibility of nutrients and energy in Atlantic salmon (Salmosalar L.) diets. Aquaculture 210, 305-321

Steel R.G., Torrie J.H., 1980. Principles and Procedures of Statistics. $2^{\text {nd }}$ Edition. New York, McGraw Hill Book

Svihus B., Herstad O., Newman C.W.,1996. Effect of high moisture storage of barley, oats and wheat on chemical content and nutritional value for broiler chickens. Acta Agr. Scand., Sect. A-Anim. Sci. 47, 39-47

Svihus B., Newman R.K., Newman C.W., 1997a. Effect of soaking germination and enzyme treatment of whole barley on nutritional value and digestive tract parameters of broiler chickens. Brit. Poultry Sci. 38, 390-396

Svihus B., Newman C.W, Newman R.K., Selmer-Olsen I., 1997b. Changes in extract viscosity, amino acid content, and soluble and insoluble $\beta$-glucan and dietary fibre content of barley during different high moisture storage conditions. Anim. Feed Sci. Tech. 64, 257-272

Taheri H.R., Moravej H., Tabandeh F., Zaghari M., Shivazad M., 2009. Screening of lactic acid bacteria toward their selection as a source of chicken probiotic. Poultry Sci. 88, 1586-1593

Williams C.H., David D.J., lismaa O., 1962. The determination of chromic oxide in faeces samples by atomic absorption spectrophotometry. J. Agr. Sci. 59, 381-385 